\title{
PENEGAKAN HUKUM TERHADAP KORPORASI YANG MELAKUKAN PENCUCIAN UANG DARI HASIL KORUPSI DI INDONESIA
}

\author{
Fachreja Effendy Nasution, Kristiawanto, Santrawan T. Paparang \\ Program Pascasarja Ilmu Hukum Universitas Jayabaya \\ Email: fachrejaeffendynst@gmail.com,drkristiawantopartners@gmail.com, \\ paparangpartners@gmail.com
}

\begin{abstract}
Abstrak
Penegakan hukum terhadap Korporasi yang melakukan tindak pidana pencucian uang, hingga saat ini masih belum dilaksanakan secara maksimal oleh penegak hukum, hal ini dikarenakan belum adanya aturan hukum yang mengatur secara jelas mengenai bentuk pertanggungjawaban Korporasi sebagai subjek hukum pidana dan masih rendahnya pemahaman penegak hukum dalam memahami eksistensi Korporasi sebagai subjek hukum pidana. Berdasarkan latar belakang tersebut, dalam penelitian ini dirumuskan masalah mengenai bagaimana mekanisme pembuktian tindak pidana pencucian uang yang dilakukan oleh Korporasi dalam kejahatan korupsi di Indonesia, juga bagaimana penegakan hukum terhadap Korporasi yang melakukan tindak pidana pencucian uang dalam kejahatan korupsi di Indonesia. Metode yang digunakan dalam penelitian ini adalah penelitian hukum normatif dengan menggunakan data sekunder yang bersumber dari bahan-bahan hukum primer, sekunder dan tertier yang dianalis dengan metode analisis yuridis kualitatif. Dari hasil penelitian diperoleh, pembuktian tindak pidana pencucian uang yang dilakukan oleh Korporasi didasari pada pertanggungjawaban pidana Korporasi sebagaimana diatur dalam Pasal 6 Undang-Undang No. 8/2010 tentang TPPU. Pemerintah bersama-sama dengan DPR harus segera merumuskan dan membuat regulasi tentang pertanggungjawaban pidana Korporasi sebagai subjek hukum tindak pidana, utamanya dalam Hukum Acara Pidana (RUU-KUHAP). Sehingga penegakan hukum terhadap tindak pidana Korporasi, utamanya tindak pidana pencucian uang yang dilakukan oleh Korporasi dapat memiliki kepastian hukum.
\end{abstract}

Kata Kunci: Penegakan Hukum, Korporasi, Pencucian Uang.

\section{Abstract}

Law enforcement against the crime of laundering committed by corporations, has not been carried out optimally. This is because there are no legal rules that clearly regulate the form of corporate responsibility as a subject of criminal law and the low understanding of law enforcement in understanding existence as a subject of criminal law. Based on this background, the research formulated the problem of how to prove the mechanism of money laundering crimes committed by 
corporations in corruption crimes in Indonesia, as well as how to enforce the law against corporations that commit money laundering crimes in corruption crimes in Indonesia. The method used in this research is normative legal research by using secondary data sourced from primary, secondary and tertiary legal materials which were analyzed using qualitative juridical analysis methods. From the research results, it can be seen that the proof of money laundering crimes committed by corporations is based on corporate criminal responsibility as stipulated in Article 6 of Law no. 8 year 2010 on ML. The government together with the DPR must immediately formulate and make regulations regarding corporate criminal liability as a legal subject for criminal acts, especially in the Criminal Procedure Code (RUU-KUHAP). So that law enforcement against corporate crimes, especially money laundering crimes committed by corporations can have legal certainty.

Keywords: Law Enforcement, Corporations, Money Laundering.

Diserahkan: 05-01-2022Ｄiterima: 25-01-2022Ｄiterbitkan: 20-02-2022

\section{Pendahuluan}

Pada mulanya korupsi hanya dipahami sebagai suatu bentuk penyalahgunaan kekuasaan yang berhubungan dengan pemerintahan, dengan demikian, korupsi hanya dianggap sebagai penyimpangan dari norma-norma yang berlaku bagi orang yang menjabat suatu jabatan di lingkungan pemerintahan. Dengan kata lain, perilaku korupsi adalah perilaku menyimpang dari tugas yang seharusnya dilakukan oleh seorang pejabat dalam pemerintahan (Elwi Danil, 2014). Tindak pidana korupsi yang dilakukan oleh Korporasi dimana Korporasi sebagai subjek hukum pidana tidak dikenal dalam KUHP maupun KUHAP, hal ini disebabkan KUHP merupakan warisan pemerintahan kolonial Belanda yang menganut sistem eropa kontinental (civil law).

Perkembangannya, kebijakan hukum pidana dalam pemberantasan tindak pidana korupsi telah memperluas subjek hukum korupsi yang tidak hanya sebatas Pegawai Negeri Sipil (PNS), pejabat negara dan/atau penyelenggara negara. Dalam UndangUndang Nomor 31 Tahun 1999 Tentang Pemberantasan Tindak Pidana Korupsi Jo Undang-Undang Nomor 20 Tahun 2001 tentang Perubahan Atas Undang-Undang Nomor 31 Tahun 1999 Tentang Pemberantasan Tindak Pidana Korupsi (Undang-Undang PPTK), juga telah memposisikan Korporasi sebagai subjek hukum tindak pidana korupsi. Diposisikannya Korporasi sebagai subjek hukum korupsi dapat dilihat dalam rumusan Pasal 1 angka 3 Undang-Undang NO. 20/2001 tentang PTPK, menyebutkan "Setiap orang adalah orang perserorangan atau termasuk Korporasi”. Pada Angka 1 disebutkan bahwa yang disebut Korporasi adalah "Kumpulan orang atau kekayaan yang terorganisasikan baik merupakan badan hukum maupun bukan badan hukum".

Doktrin hukum pidana secara umum mengakui bahwa untuk adanya pertanggungjawaban pidana mengharuskan adanya kesalahan. Adanya kesalahan adalah salah satu asas yang dianut dalam menuntut pertanggungjawaban pidana, yang dalam 
hukum pidana sering dikenal dengan istilah "tiada pidana tanpa kesalahan" (Chairul Huda, 2014).

Pada perkembangannya, kejahatan korupsi memiliki potensi berkorelasi dengan tindak pidana pencucian uang, oleh karena itu Pemerintah mengeluarkan Undang-Undang No. 8 Tahun 2010 tentang Tindak Pidana Pencucian Uang, menunjukkan komitmen dan political will dari pemerintahan negara Republik Indonesia dalam melawan dan memerangi praktik pencucian uang.

Persoalan yang timbul terhadap Korporasi yang melakukan tindak pidana pencucian uang dari hasil korupsi di indonesia adalah bagaimana mekanisme pembuktian tindak pidana pencucian uang yang dilakukan oleh Korporasi dalam kejahatan korupsi di Indonesia, juga bagaimana penegakan hukum terhadap Korporasi yang melakukan tindak pidana pencucian uang dalam kejahatan korupsi di Indonesia.

Salah satu contoh kasus tindak pidana pencucian uang yang bersumber dari tindak pidana korupsi adalah kasus tindak pidana pencucian uang yang dilakukan oleh PT Putra Ramadhan atau PT Tradha. Perusahaan tersebut merupakan milik Bupati Kebumen nonaktif Muhammad Yahya Fuad, yang diduga melakukan pencucian hasil kejahatan korupsi yang dilakukan oleh Bupati Kebumen non-aktif Muhammad Yahya Fuad, dengan cara menyembunyikan atau menyamarkan uang hasil korupsi dan gratifikasi yang diterima oleh Yahya sepanjang 2016-2017.

Komisi Pemberantasan Korupsi menetapkan status tersangka dalam kasus pidana pencucian uang kepada PT Tradha dalam kurun waktu 2016 - 2017, PT Tradha menggunakan bendera milik lima perusahaan lainnya untuk memenangi delapan proyek di Kebumen, Jawa Tengah, dengan nilai total proyek Rp 51.000.000.000 (lima puluh satu miliar rupiah). Hal itu dilakukan untuk menutupi kecurigaan adanya potensi konflik kepentingan atau conflict of interest dalam lelang dan pelaksanaan proyek. Perbuatan tersebut dinilai melanggar Pasal 12 huruf i Undang-Undang No. 20 Tahun 2001 Tentang PTPK. Dugaan penerimaan suap, gratifikasi, dan benturan kepentingan dalam pengadaan itu diduga sebagai tindak pidana asal dalam penyidikan ini atau merupakan predicate crime dalam penyidikan dugaan tindak pidana pencucian uang dengan tersangka PT Tradha.

Tindak pidana pencucian uang yang dilakukan oleh Korporasi memiliki dampak hukum yang sangat luas, sehingga perlu dilakukan penelaahan lebih mendalam untuk meminimalisir akibat hukum yang terjadi. Hal ini menjadi salah satu konsern para Akademisi untuk membuat kajian hukum terkait tindak pidana pencucian uang yang dilakukan oleh Korporasi sebagaimana dimuat di dalam beberapa penelitian hukum sebelumnya sebagai berikut:

1. Tesis oleh Naomi Ester, mahasiswa Program Studi Pascasarjana Ilmu Hukum Universitas Jayabaya, (Naomi Ester, 2014).

Pada penelitian yang dilakukan oleh Naomi Ester mengangkat judul penelitian tentang: "Penegakan Hukum Tentang Tindak Pidana Pencucian Uang (Money Laundring) Kaitannya dengan Penerapan Kerahasiaan Bank Sebagai Suatu Wujud Pembangungan Perbankan”. Dalam penelitian ini ditentukan dua permasalahan 
yang menjadi objek kajian dan pembahasan penelitian, yaitu: 1) Bagaimana penerapan atas pengaturan tentang kerahasiaan Bank ?2) Bagaimana upaya atas kerahasiaan Bank terhadap tindak pidana Pencucian Uang (Money Laundring) ?.

2. Tesis oleh Supono, mahasiswa Program Studi Pascasarjana Ilmu Hukum Universitas Jayabaya, (Supono,2016).

Pada penelitian yang dilakukan oleh Supono mengangkat judul penelitian tesis tentang: "Beban Pembuktian Terbalik Tindak Pidana Pencucian Uang Dalam Perspektif Teori Pembuktian Pada Sistem Peradilan Pidana di Indonesia”. Dalam penelitian ini ditentukan dua rumusan masalah yang menjadi objek kajian dan pembahasan penelitian, yaitu: 1) Bagaimana penerapan Undang-Undang beban pembuktian terbalik terhadap tindak pidana pencucian uang dalam sistem hukum pidana di Indonesia ? 2) Bagaimana Undang-Undang beban pembuktian terbalik tindak pidana pencucian uang dalam perspektif Putusan Mahkamah Agung RI ?

3. Tesis oleh Lisa, mahasiswa Program Studi Pascasarjana Ilmu Hukum Universitas Jayabaya, (Lisa, 2018)

Pada penelitian yang dilakukan oleh Lisa mengangkat judul penelitian tesis tentang: "Peran Perbankan Dalam Mencegah dan Menanggulangi Praktek Tindak Pidana Pencucian Uang dan Dampaknya Terhadap Kegiatan Perbankan Secara Online". Dalam penelitian ini ditentukan tiga rumusan masalah, yaitu: 1) Bagaimanakah peran dan mekanisme yang diterapkan oleh lembaga perbankan di Indonesia dalam rangka mencegah dan menanggulangi praktek tindak pidana pencucian uang, terutama praktek tindak pidana pencucian uang yang dilakukan secara online. 2) Bagaimanakah kendala-kendala yang dihadapai lembaga perbankan di Indonesia dalam mewujudkan perannya tersebut. 3) Bagaimanakah kajian yuridis berlandaskan pada Undang-Undang No. 8 Tahun 2010 tentang TPPU, Undang-Undang No. 20 Tahun 2001 tentang PTPK, dan Undang-Undang ITE, dalam rangka mencegah dan menanggulangi praktek tindak pidana pencucian uang serta dampaknya terhadap perbankan secara online.

Adapun yang menjadi permasalahan dari penelitian ini adalah 1). Bagaimana mekanisme Pembuktian Tindak Pidana Pencucian Uang yang dilakukan oleh Korporasi., 2). Bagaimana pertanggungjawaban pidana Korporasi dalam konteks Penegakan Hukum Tindak Pidana Pencucian Uang dari hasil Korupsi.

Berdasarkan uraian yang telah dijabarkan di atas, penulis berpandangan bahwa perlu adanya penelitian lebih lanjut terkait penegakan hukum terhadap Korporasi yang melakukan tindak pidana pencucian uang, karena hingga saat ini masih belum dipergunakan secara maksimal oleh penegak hukum untuk menjerat Korporasi sebagai subjek hukum ke Pengadilan.

\section{Metode Penelitian}

Metode yang digunakan dalam penelitian ini adalah penelitian hukum normatif dengan menggunakan data sekunder yang bersumber dari bahan-bahan hukum primer, sekunder dan tertier yang dianalis dengan metode analisis yuridis kualitatif. 
Metode kualitatif yaitu data penelitian diolah dan dianalisis berdasarkan kualitas dan kebenarannya lalu dideskripsikan dalam bentuk kalimat yang sistematis dan dapat dimengerti, sehingga dapat ditarik sebuah kesimpulan. Penarikan kesimpulan pada penelitian ini menggunakan metode deduktif yang menggunakan cara analisis dari kesimpulan umum yang diuraikan menjadi contoh-contoh kongkrit atau fakta-fakta untuk menjelaskan kesimpulan dan berakhir pada suatu kesimpulan yang lebih khusus.

Adapun metode pendekatan yang digunakan dalam penelitian ini adalah pendekatan perundang-undangan (statute approach), pendekatan konseptual (conseptual approach), dan pendekatan kasus (case approach). Sebagai penelitian hukum normatif, maka jelas bahwa dalam menganalisis setiap permasalahan yang dikemukakan dalam penelitian ini akan senantiasa mengacu pada ketentuan peraturan perundang-undangan yang berlaku sebagai hukum positif, diantarnaya adalah Undang-Undang Nomor 31 Tahun 1999 tentang Pemberantasan Tindak Pidana Korupsi jo Undang-Undang Nomor 20 Tahun 2001 tentang Perubahan Atas Undang-Undang Nomor 31 Tahun 1999 tentag Pemberantasna Tindak Pidana Korupsi, selain juga mengacu pada ketentan UndangUndang Nomor 8 Tahun 2010 tentang Pencucian Uang, Undang-Undang 40 Tahun 2007 tentang Perseroan Terbatas dan berbagai peraturan perundang-undangan yang relevan lainnya.

Selanjutnya juga dalam penelitian tesis ini juga menggunakan pendekatan konseptual (conseptual approach). Pendekatan konseptual adalah suatu pendekatan yang mencoba untuk menganalisis permasalahan penelitian melalui berbagai doktrin hukum pidana atau pun berbagai pandangan atau pendapat para ahli hukum, utamanya pendapat ahli hukum pidana mengenai penegakan hukum tindak pidana pencucian uang dari hasil kejahatan korupsi yang dilakukan oleh korporasi.

Selain pendekatan peraturan perundang-undangan dan pendekatan konseptual, juga digunakan pendekatan kasus (case approach). Pendekatan ini dilakukan dengan cara menganalisis berbagai putusan pengadilan terkait dengan penegakan hukum tindak pidana pencucian uang berdasarkan hasil korupsi yang dilakukan oleh perusahaan.

\section{Hasil dan Pembahasan}

\section{A. Penegakan Hukum Dalam Konteks Pembuktian Terbalik}

Penerapan sistem pembuktian terbalik secara absolut atau murni dapat juga dianggap sebagai penggunaan asas praduga bersalah secara mutlak, di mana tersangka atau terdakwa dianggap bersalah sampai dirinya dapat membuktikan bahwa dirinya tidak melakukan suatu tindak pidana tanpa ada kewajiban bagi penuntut umum untuk membuktikannya.

Penerapan sistem pembuktian terbalik secara absolut atau murni mengandung potensi penyalahgunaan kewenangan dari para penegak hukum. Penyalahgunaan dapat terjadi pada tingkat penyidikan, ketika penyidik di dalam penyitaan barang bukti berupa uang maupun aset milik tersangka tidak mengindahkan kaidah-kaidah tentang penyitaan di dalam hukum acara, karena dalam benak penyidik bahwa tersangkalah nantinya di 
persidangan yang akan membuktikan bahwa uang dan aset yang disita tersebut bukan merupakan hasil dari tindak pidana.

Penerapan secara absolut atau murni ini disikapi berbeda oleh Indriyanto Seno Adji dengan pernyataannya, "bahwa sistem pembuktian terbalik tidak pernah bersifat total absolut, yang artinya pembuktian terbalik hanya dapat diterapkan secara terbatas, yaitu hanya terhadap delik yang berkenaan dengan gratifikasi (pemberian) yang berkaitan dengan suap (bribery)." (Indriyanto Seno Adji, 2009)

Potensi penyalahgunaan wewenang terjadi sebaliknya, ketika penyidik berusaha untuk bernegosiasi dengan tersangka dalam rangka penyitaan uang dan aset tersebut, meminta uang atau fasilitas lainnya dengan alasan bahwa semua aset dan uang milik tersangka dapat saja disita oleh penyidik, dan tersangka nantinya yang harus membuktikan di persidangan bahwa uang dan aset tersebut bukan berasal dari hasil tindak pidana. Demikian halnya pada tingkat kejaksaan, jaksa penuntut umum yang integritas moralnya tidak baik, membuka peluang negosiasi terhadap terdakwa untuk menuntut atau tidak menuntut uang dan aset milik terdakwa disita oleh negara dalam persidangan.

Shinto Bina Gunawan Silitonga, menjelaskan bahwa indikasi ini pula yang tercium dalam perkara Bahasyim Assifie, sebagaimana ditulis oleh Majalah Tempo yang mengendus perilaku jaksa penuntut umum yang bernegosiasi terhadap rencana tidak disitanya oleh negara uang Bahasyim Assifie senilai Rp. 64 milyar, karena predicate offence yang masuk dalam berkas perkara adalah pemberian uang Rp. 1 milyar dari Kartini Mulyadi kepada Bahasyim Assifie. Jika negosiasi itu mendapat kata mufakat, maka Bahasyim Assifie tidak harus membuktikan sumber uang Rp. 64.000.0000.0000 (enam puluh empat miliar) miliknya, karena jaksa penuntut umum akan mendakwa hanya terhadap Rp. 1.000.000.000 (satu miliar rupiah) (Shinto Bina Gunawan Silitonga, 2011).

Kegiatan pembuktian suatu tindak pidana tidak lagi berfokus mencari alat-alat bukti dari suatu kejahatan, melainkan fokus pada pemeriksaan alat-alat bukti yang akan ditampilkan oleh Jaksa Penuntut Umum di muka persidangan. Secara umum, kegiatan pembuktian dapat dibedakan ke dalam 2 (dua) jenis (Adami Chazawi, 2006) yaitu :

1. Kegiatan pengungkapan fakta, yakni kegiatan pemeriksaan terhadap alat-alat bukti yang diserahkan oleh penuntut umum di muka persidangan dan penasihat hukum. Proses ini akan berakhir ketika hakim menyatakan secara lisan dalam proses sidang bahwa pemeriksaan perkara sudah selesai, dalam artian pemeriksaan yang dilakukan untuk mengungkap fakta-fakta dari alat-alat bukti dan barang bukti yang diserahkan dalam sidang termasuk pemeriksaan setempat telah selesai dilaksanakan.

2. Bagian penganalisaan fakta dan sekaligus analisis hukum, yang merupakan bagian dari pembuktian terhadap fakta-fakta yang didapat selama berlangsungnya persidangan, yang dianalisa oleh Jaksa Penuntut Umum dalam tuntutan (requisitoir), oleh penuntut umum dalam pembelaan (pledoi), dan oleh hakim dalam putusannya (vonis).

Untuk menghindari terjadinya penyalahgunaan wewenang dalam kegiatan pembuktian, maka dibutuhkan perangkat hukum yang mengatur tentang bagaimana cara 
dilaksanakanya proses pembuktian, yang lazim disebut sebagai hukum pembuktian. Dalam pembuktian perkara pidana, maka mekanisme pembuktian di muka persidangan secara rinci telah diatur dan diuraikan dalam Kitab Undang-Undang Hukum Acara Pidana (KUHAP) yang merupakan pedoman hukum acara pidana di Indonesia.

Meskipun pembuktian terbalik sangat di perlukan dalam proses pembuktian tindak pidana pencucian uang yang memiliki kompleksitas tinggi, Pembuktian terbalik juga banyak dikritisi oleh para ahli hukum pidana, dan menjadi polemik dalam penerapannya (Sahuri Lasmadi, Elly Sudarti, 2021), karena penerapan pembalikan beban pembuktian secara murni dapat menyebabkan beralihnya asas praduga tidak bersalah (presumption ofinnocent) menjadi asas praduga bersalah (presumption of guilt) dan relatif cenderung dianggap sebagai pengingkaran terhadap asas-asas yang telah berlaku secara universal (Afrianto Sagita, 2017).

Berdasarkan hal tersebut diatas maka perlu dibentuk suatu aturan hukum yang baku untuk menjadi tolak ukur penegak hukum dalam melakukan proses pembuktian terhadap para pelaku tindak pidana pencucian uang khususnya terhadap subjek hukum Korporasi.

\section{B. Korporasi Sebagai Subjek Hukum}

Tindak pidana korporasi dalam beberapa literatur sering disebut juga dengan istilah "kejahatan korporasi". Oleh karenganya, istilah tindak pidana korporasi dan kejahatan korporasi seringkali digunakan secara bergantian. Tindak pidana korporasi pada dasarnya tidaklah muncul dengan sendirinya, melainkan muncul seiring dengan perkembangan zaman dan perkembangan masyarakat.

Awal mula lahirnya tindak pidana korporasi berangkat dari pendapat Edwin Sutherland yang mengemukakan jenis-jenis kejahatan atau tindak pidana baru yang dikenal dengan white collar crime (kejahatan kerah putih).Yusuf Shofie, mengatakan bahwa white collar crime sering diasosiasikan dengan berbagai skandal dunia keuangan dan bisnis dan penipuan canggih yang dilakukan oleh para eksekutif senior, yang di dalamnya termasuk apa yang secara populer dikenal sebagai tindak pidana atau kejahatan korporasi (corporate crime) (Yusuf Shofie, 2002).

Penempatan korporasi sebagai subjek dalam hukum pidana tidak dapat dilepaskan dari modernisasi sosial. Di mana semakin modern suatu masyarakat, maka semakin kompleks sistem sosial, ekonomi, dan politik, yang menuntut kebutuhan akan sistem pengendalian kehidupan yang formal akan menjadi semakin besar pula. Undang-Undang Nomor 1 Tahun 1946 tentang Kitab Undang-undang Hukum Pidana (KUHP) hanya mengenal orang perseorangan sebagai subjek hukum pidana. Dengan kata lain, KUHP belum mengenal dan memandang korporasi sebagai subjek hukum pidana.

KUHP hanya mengenal manusia alamiah (natural person) sebagai satu-satunya subjek hukum pidana. Hal ini dapat ditelusuri dari ketentuan KUHP yang memandang suatu delik hanya dapat dilakukan oleh manusia, utamanya dalam Pasal 59 KUHP yang berbunyi: "Dalam hal-hal di mana pelanggaran ditentukan pidana terhadap pengurus anggota-anggota badan pengurus atau komisaris-komisaris, maka pengurus, anggota badan pengurus, atau komisaris yang ternyata tidak ikut campur melakukan pelanggaran 
tidak dipidana (Muladi dan Dwidja Priyatno, 2010). Menurut Muladi dan Hamzah Hatrick, ada beberapa alasan pembenar dalam memposisikan korporasi sebagai subjek hukum pidana, yaitu:

1. Atas dasar falsafah integraliastik, yaitu segala sesuatu hendaknya diukur atas dasar keseimbangan, keselarasan dan keserasian antara kepentingan individu dan kepentingan sosial;

2. Atas dasar asas kekeluargaan dalam Pasal 33 UUD 1945;

3. Untuk memberantas anomie of success (sukes tanpa aturan);

4. Untuk perlindungan konsumen;

5. Untuk kemajuan teknologi. Adanya pengakuan terhadap korporasi sebagai subjek hukum pidana, tampaknya sudah mendunia.

Sementara itu, alasan tidak dimaksukkan Korporasi sebagai subjek hukum pidana dalam KUHP Jan Remmelink, memberikan penjelasan sebagai berikut:

Awalnya pembuat undang-undang berpandangan bahwa hanya manusia (orang perorangan/individu) yang dapat menjadi subjek hukum pidana, sedangkan korporasi tidak dapat menjadi subjek hukum pidana. Adanya pandangan seperti itu dapat ditelusuri dari sejarah perumusan ketentuan Pasal 51. Sr. (Pasal 59 KUHP) terutama dari cara perumusan delik yang selalu dimulai dengan frasa hij die (barangsiapa) (Jan Remmelink, 2003). Pada tahun 1976 pembentuk undang-undang di Belanda telah memutuskan untuk merubah Pasal 51 KUHP berdasarkan Undang-Undang tanggal 23 Juni 1976, Lembaran Negara No. 377. Menurut ketentuan yang baru ini, semua tindak pidana dapat dilakukan oleh orang dan korporasi.

Ketentuan yang tercantum dalam Pasal 51 itu telah ada sejak tahun 1951 dalam hukum pidana ekonomi (Pasal 15 Eeconomic Penal Code). Akan tetapi, ketentuan pasal dalam bidang ekonomi tersebut telah dicabut pada tahun 1976, yang berarti telah mengakhiri doktrin fiksi. Perundang-undangan yang baru itu, berlaku untuk hukum pidana umum dan hukum pidana ekonomi, yaitu berdasarkan ide bahwa korporasi merupakan badan hukum dan dapat melakukan tindak pidana.

Oemar Seno Adji menyatakan bahwa dengan adanya pemidanaan terhadap persekutuan, didasarkan tidak saja atas pertimbangan kemanfataan (utilitis), tetapi juga atas dasar-dasar kebenaran teoritis. Di Indonesia kedudukan korporasi yang merupakan badan hukum sebagai subjek hukum pidana telah dijelaskan di dalam suatu putusan Mahkamah Agung Republik Indonesia Nomor 136/Kr/1966, tertanggal 1 Maret 1966 dalam perkara PT Kosmo dengan PT Sinar Sahara, yang menyatakan bahwa: "Suatu korporasi tidak dapat disita", pandangan Mahkamah Agung, menunjukkan bahwa korporasi adalah sebagai subjek hukum. Oleh karenanya, korporasi atau badan hukum tidak dapat disita, yang dapat disita adalah harta benda, sementara badan hukum adalah subjek hukum. Dengan demikian, putusan Mahkamah Agung tersebut menegaskan bahwa badan hukum (korporasi) merupakan subjek hukum dalam hukum pidana (Chaidir Ali, 1992).

Berdasarkan uraian di atas, dapat dikakatan bahwa kedudukan korporasi sebagai subjek hukum pidana semestinya tidak lagi menjadi polemik hukum. Terlebih lagi dalam 
perkembangannya, berbagai undang-undang yang berlaku sebagai hukum positif di Indonesia, seperti Undang-Undang No. 20 Tahun 2001 Tentang PTPK dan UndangUndang TPPU dan berbagai undang-undang yang bersifat khusus lainnya telah mengatur secara eksplisit mengenai kedudukan korporasi sebagai subjek hukum pidana.

\section{Sistem Pertanggungjawaban Pidana Korporasi}

Eksistensi korporasi sebagai subjek hukum pidana, maka menimbulkan konsekuensi hukum dapat dituntutnya korporasi secara pidana atau dapat dipertanggungjawab-pidanakannya korporasi. Berkenanaan dengan sistem pertanggungjawaban pidana pada korporasi, menurut Mardjono Reksodiputro terdapat 3 (tiga) bentuk sistem pertanggungjawaban korporasi, yaitu sebagai berikut:

1. Pengurus korporasi sebagai pelaku dan penguruslah yang bertanggungjawab;

2. Korporasi sebagai pelaku dan pengurus lah bertanggungjawab;

3. Korporasi sebagai pelaku dan Korporasi juga sebagai yang bertanggungjawab.

Dalam menuntut pertanggungjawaban pidana terhadap korporasi, maka terapat beberapa doktrin yang dapat menjadi dasar pembenar dalam meminta pertanggungjawaban secara pidana terhadap korporasi, yaitu:

1. Identification Theory (teori identifikasi)

Doktrin Identification Theory merupakan doktrin pertama yang membenarkan atau dasar pembenar menuntut pertanggungjawaban pidana korporasi. Doktrin pertanggungjawaban pidana langsung atau doktrin identifikasi adalah salah satu teori yang digunakan sebagai alasan pembenar dalam meminta pertanggungjawaban korporasi, meskipun korporasi bukanlah sesuatu yang dapat berdiri sendiri. Menurut doktrin ini, korporasi dinilai dapat melakukan tindak pidana secara langsung melalui "pejabat senior" (officer senior), yang diidentifikasi sebagai perbuatan dari korporasi itu sendiri. Dengan demikian, perbuatan "pejabat senior" akan dipandang sebagai perbuatan korporasi.

2. Strict liability atau Absolute Liability (pertanggungjawaban mutlak).

Doktrin kedua yang mendukung pertanggungjawaban pidana korporasi adalah Strict liability atau absolute liability yang dalam beberapa literatur disebut juga dengan pertanggungjawaban tanpa kesalahan atau disebut dengan no-fault liability. Dalam doktrin ini, terhadap korporasi dapat dimintai pertanggungjawaban pidana tanpa adanya keharusan untuk membuktikan adanya kesalahan dari pelaku tindak pidana. Doktrin pertanggungjawaban pidana strict liability dapat dikatakan sebagai doktrin yang mengenyampingkan asas kesalahan yang berlaku secara mutlak dan mendasar dalam hukum pidana.

Menurut Hamzah Hatrik, bahwa yang dimaksud strict liability adalah pertanggungjawaban tanpa kesalahan, yang dalam hal ini si pembuat sudah dapat dipidana, jika seseorang telah melakukan perbuatan yang dilarang sebagaimana telah dirumuskan dalam undang-undang, tanpa melihat lebih jauh sikap batin si pembuat. Lebih lanjut, Siswanto Sunarso menyatakan strict liability adalah suatu bentuk pertanggungjawaban pidana, di mana seseorang sudah dapat dimintai 
pertanggungjawaban pidana untuk tindak pidana tertentu, meskipun pada diri orang itu tidak ada kesalahan (means rea). Secara singkat dapat dipahami bahwa strict liability adalah pertanggungjawaban tanpa kesalahan (Siswanto Sunarso, 2005).

Berdasarkan uraian tersebut di atas, dapat dipahami bahwa penerapan strict liability hanya berlaku untuk tindak pidana tertentu saja yang ditetapkan oleh undangundang. Dalam hal ini, pelaku tindak pidana akan dibebani pertangungjawaban tanpa harus dibuktikan terlebih dahulu adanya kesalahan (mens rea) ketika perbuatan (actus reus) dilakukan.

Berdasarkan uraian di atas, dapat disimpulkan bahwa dalam menuntut atau meminta pertanggungjawaban korporasi begitu banyak teori yang dapat digunakan. Masing-masing teori memiliki kelemahan dan juga kelebihan, sehingga tidak semua teori yang ada dapat dipakai untuk memintai pertanggungjawaban pidana kepada korporasi. Selanjutnya dalam ayat (2) ditentukan: Pidana dijatuhkan terhadap Korporasi apabila tindak pidana Pencucian Uang:

1. dilakukan atau diperintahkan oleh Personil Pengendali Korporasi;

2. dilakukan dalam rangka pemenuhan maksud dan tujuan Korporasi;

3. dilakukan sesuai dengan tugas dan fungsi pelaku atau pemberi perintah;

4. dilakukan dengan maksud memberikan manfaat bagi korporasi.

Mengacu pada ketentuan Pasal 6 tersebut di atas, dapat dipahami bahwa yang dapat dipertanggungjawabkan dalam hal tindak pidana pencucian uang yang dilakukan oleh korporasi adalah Korporasi dan/atau Personil Pengendali Korporasi. Unsur subjektif, yaitu pelaku sebagai subjek hukum orang atau organisasi (badan hukum). Unsur subjektif ini berkaitan dengan unsur kesalahan yaitu sengaja (opzet) dan atau kelalaian (culpa). Bentuk kesalahan yang dirumuskan dalam Pasal 3, Pasal 4, dan Pasal 5, khususnya terdapat frasa kalimat yang menyatakan bahwa "...harta kekayaan yang diketahuinya atau patut diduganya merupakan hasil tindak pidana”. Dari frasa kalimat tersebut, maka dapat dipastikan bahwa unsur subjektif yang terkandung dalam tindak pidana pencucian uang yang dirumuskan dalam Pasal 3 s.d Pasal 5 Undang-Undang No. 8 Tahun 2010 tentang TPPU tidak saja unsur kesengajaan (dolus), tetapi juga unsur kealpaan yang dialternatifkan sebagai bentuk kesengajaan.

Dari ketentuan di atas, dapat dikatakan bahwa ketentuan Pasal 3, Pasal 4 dan Pasal 5 Undang-Undang No. 8 Tahun 2010 tentang TPPU, termasuk dalam bentuk kealpaan yang tidak sesungguhnya. Hal tersebut dapat dilihat dari rumusan Pasal 5 ayat (1) Undang-Undang TPPU, yang menyatakan bahwa yang dimaksud dengan "Patut diduganya" adalah suatu kondisi yang memenuhi setidak-tidaknya pengetahuan, keinginan, atau tujuan pada saat terjadinya transaksasi yang diketahuinya yang menunjukkan pelanggaran hukum.

Unsur pokok dari setiap perbuatan pidana adalah adanya sifat melawan hukum. Sifat melawan hukum dalam tindak pidana pencucian uang sebagaimana dirumuskan dalam Pasal 3, 4, dan Pasal 5 Undang-Undang No.8 Tahun 2010 tentang TPPU, seyogyanya sejalan dengan Pasal 2 yang menjelaskan bahwa adanya tindak pidana asal dalam tindak pidana pencucian uang. Dengan kata lain, untuk menetapkan telah 
terjadinya suatu tindak pidana pencucian uang, maka terlebih dahulu dibuktikan adanya tindak pidana asal

Jika mencermati Pasal 2 s.d Pasal 5 Undang-Undang No. 8 Tahun 2010 tentang TPPU, memang tidak ada mensyaratkan bahwa untuk dapat melakukan penyidikan, penuntutan dan pemeriksaan terhadap tindak pidana pencucian harus terlebih dahulu diperiksa tindak pidana asalnya atau dibuktikan terlebih dahulu tindak pidan asalnya. Akan tetapi, berdasarkan logik hukum, jika tindak pidana pencucian uang adalah merupakan suatu usaha untuk menyamarkan harta kekayaan dari hasil kejahatan, maka tentunya terlebih dahulu harus dipastikan terlebih dahulu mengenai kejahatan asal yang menjadi sumber dari harta kekayaan yang akan dan/atau disembunyikan atau disamarkan oleh pelaku tindak pidana pencucian uang. Dengan kata lain, tanpa adanya tindak pidana asal, maka akan mustahil terpenuhi unsur-unsur dari tindak pidana pencucian uang.

Menurut penulis, bahwa ketentuan Pasal 69 Undang-Undang No. 8 Tahun 2010 telah menimbulkan ketidakpastian hukum dalam penegakan hukum tindak pidana pencucian uang. Seyogyanya, terlebih dahulu harus dibuktikan adanya kejahatan asal atau paling tidak antara tindak pidana asal diperiksa secara bersamaan dengan tindak pidana pencucian uang.

Memperhatikan penjelasan Pasal 6 ayat (1) tersebut di atas, maka terlihat jelas bahwa ketentuan Pasal 6 ayat (1) telah memperluas pengertian korporasi sebagaimana dimaksud dalam Pasal 1 angka 10 Undang-Undang No.8 Tahun 2010, yang menyebutkan bahwa Korporasi yaitu sebagai kumpulan orang dan/atau kekayaan yang terorganisasi, baik merupakan badan hukum maupun bukan badan hukum.

Selain itu, dalam Undang-Undang No. 8 Tahun 2010 tentang TPPU tidak saja mengatur tentang subjek hukum korporasi, tetapi juga mengatur tentang pertanggungjawaban dari organ korporasi yang disebut pengendali korporasi. Namun, formulasi Pasal 6 ayat (2) yang demikian berpotensi menimbulkan permasalahan dalam praktek penegakan hukum, karena dalam penjelasan Pasal 6 ayat (2) tidak memberikan penjelasan lebih lanjut mengenai persyaratan penjatuhan pidana terhadap korporasi dalam kaitannya dengan tindak pidana pencucian, apakah persayaratan sebagaimana dimaksud dalam Pasal 6 ayat (2) tersebut bersifat kumulatif. Artinya harus memenuhi keempat syarat tersebut secara bersamaan yaitu:

1. Dilakukan atau diperintahkan oleh personil pengendali korporasi;

2. Dilakukan dalam rangka pemenuhan maksud dan tujuan Korporasi;

3. Dilakukan sesuai dengan tugas dan fungsi pelaku atau pemberi pemerintah; dan

4. Dilakukan dengan maksud memberikan manfaat bagi korporasi.

Harus diakui bahwa dengan mencermati keempat syarat sebagaimana dimaksudkan dalam Pasal 6 ayat (2) tersebut, dapat dibayangkan sulitnya apabila dimaknai sebagai syarat kumulatif. Namun demikian sejalan dengan semangat penyusun UU No. 8 Tahun 2010 tentang TPPU, di mana penyusun undang-undang menghendaki adanya perluasan dapat dipidananya subjek hukum pelaku tindak pidana pencucian uang yang tidak hanya terbatas pada subjek hukum orang, tetapi juga subjek hukum korporasi, 
nampaknya yang dimaksud dengan syarat pertanggungjawaban pidana korporasi sebagaimana dimaksud oleh penyusun undang-undang adalah bersifat alternatif, artinya dengan terpenuhinya salah satu syarat maka pertanggungjawaban pidana dengan subjek hukum korporasi dapat diterapkan.

Pemaknaan bukan tanpa dasar, karena syarat Pasal 6 ayat (2) ini hanya ingin menampilkan bahwa perbuatan yang akan dipidana itu adalah merupakan representasi dari kehendak korporasi, jadi bukan orang perorangan yang menghendaki terjadinya perbuatan yang dapat dikategorikan sebagai tindak pidana pencucian uang dari keempat syarat tersebut, terpenuhinya salah satu syarat saja, sudah menunjukkan bahwa perbuatan pidana atau peristiwa pidana itu merupakan representasi yang atau dapat menggambarkan bahwa itu merupakan kehendak dari korporasi. Sebagai contoh, dengan dipenuhinya syarat Pasal 6 ayat (2) huruf (a) yaitu dilakukan atau diperintahkan oleh personil pengendali korporasi, maka hal itu berarti bahwa peristiwa pidana atau perbuatan pidana itu terjadi karena diperintahkan oleh personil pengendali korporasi, artinya merupakan tindakan resmi dari korporasi atau on behalf of corporation. Terkait belum adanya regulasi yang baku untuk menjerat Korporasi menjadi tersangka/terdakwa yang melakukan tindak pidana, untuk mengatasi keterbatasan regulasi tersebut dalam menuntut korporasi sebagai subjek hukum pidana, maka kemudian Mahkamah Agung menerbitkan Peraturan Mahkamah Agung Nomor 13 Tahun 2016 tentang Tata Cara Penanganan Perkara Tindak Pidana Korporasi (Perma No. 13/2016 tentang Penanganan Perkara Tindak Pidana Korporasi).

Tujuan penerbitkan Perma No. 13 Tahun 2016 adalah untuk mengisi kekosongan hukum mengenai keterbatasan regulasi mengenai pertanggungjawaban korporasi sebagai subjek hukum pidana. Hal ini dapat dilihat dalam dasar menimbang Perma No. 13 Tahun 2016, yang menyebutkan: Bahwa banyak undang-undang di Indonesia menempatkan korporasi sebagai subjek tindak pidana yang dapat dimintai pertanggungjawaban, namun perkara dengan subjek hukum korporasi yang diajukan dalam proses pidana masih sangat terbatas, salah satu penyebabnya adalah prosedur dan tata cara pemeriksaan korporasi sebagai pelaku tindak pidana belum jelas, oleh karena itu dipandang perlu adanya pedoman bagi aparat penegak hukum dalam penanganan perkara pidana yang dilakukan oleh korporasi. Menjatuhkan pidana terhadap Korporasi, maka Hakim dapat menilai kesalahan Korporasi, antara lain:

1. Korporasi dapat memperoleh keuntungan atau manfaat dari tindak pidana tersebut atau tindak pidana tersebut dilakukan untuk kepentingan Korporasi;

2. Korporasi membiarkan terjadinya tindak pidana; atau

3. Korporasi tidak melakukan langkah-langkah yang diperlukan untuk melakukan pencegahan, mencegah dampak yang lebih besar dan memastikan kepatuhan terhadap ketentuan hukum yang berlaku guna menghindari terjadinya tindak pidana.

Selanjutnya, Perma No. 13 Tahun 2016 menentukan bahwa dalam hal seorang atau lebih Pengurus Korporasi berhenti, atau meninggal dunia tidak mengakibatkan hilangnya pertanggungjawaban Korporasi. Kemudian, apabila tindak pidana dilakukan 
oleh Korporasi dengan melibatkan induk Korporasi dan/atau Korporasi subsidiari dan/atau Korporasi yang mempunyai hubungan dapat dipertanggungjawabkan secara pidana sesuai dengan peran masing-masing. Pertanggungjawaban pidana terhadap suatu korporasi hanya dikenakan sebatas nilai harta kekayaan atau aset yang ditempatkan terhadap Korporasi yang menerima penggabungan atau Korporasi hasil peleburan. Dalam hal terjadi pemisahan Korporasi, maka pertanggungjawaban pidana dikenakan terhadap Korporasi yang dipisahkan dan/atau Korporasi yang melakukan pemisahan dan/atau kedua-duanya sesuai dengan peran yang dilakukan. Jika Korporasi sedang dalam proses pembubaran, maka pertanggungjawaban pidana tetap dikenakan terhadap Korporasi yang akan dibubarkan.

Korporasi yang telah bubar setelah terjadinya tindak pidana tidak dapat dipidana, akan tetapi terhadap aset milik Korporasi yang diduga digunakan untuk melakukan kejahatan dan/atau merupakan hasil kejahatan, maka penegakkan hukumnya dilaksanakan sesuai dengan mekanisme sebagaimana diatur dalam peraturan perundangundangan.

\section{Kesimpulan}

Penegakan hukum tindak pidana pencucian uang yang dilakukan oleh korporasi didasari pada pertanggungjawaban pidana korporasi sebagaimana diatur dalam Pasal 6 Undang-Undang No. 8 Tahun 2010 tentang TPPU. Mekanisme pembuktian tindak pidana pencucian uang yang dilakukan oleh korporasi secara umum mengacu pada KUHAP. Namun, KUHAP tidak mengatur mengenai pertanggungjawaban pidana dari Korporasi, sehingga terjadi kekosongan hukum. Mengisi kekosongan hukum acara pidana mengenai pertanggungjawaban pidana korporasi dari aspek formil, Mahkamah Agung telah menerbitkan Perma No. 13 Tahun 2016 tentang Tata Cara Penanganan Perkara Pidana oleh Korporasi yang menjadi pedoman bagi penegak hukum dalam penanganan perkara tindak pidana korporasi.

Secara khusus, menurut Pasal 77 dan Pasal 78 Undang-Undang No. 8 Tahun 2010 tentang TPPU mekanisme pembuktian tindak pidana pencucian uang, baik itu dilakukan oleh orang perseorangan maupun korporasi, dilaksanakan dengan beban pembuktian terbalik, namun hal tersebut perlu memperhatikan hak asasi tersangka atau terdakwa yang diduga telah melakukan tindak pidana pencucian uang dengan mengedepankan keseimbangan secara proporsional antara perlindungan kemerdekaan individu di satu sisi dan perampasan hak individu yang bersangkutan atas harta kekayaan milik pelaku yang diduga kuat berasal dari hasil tindak pidana korupsi disisi lainnya agar tidak bertentangan dengan asas praduga tidak bersalah (presumption of innocence) dan rasa keadilan. Hal tersebut dikarenakan belum adanya aturan hukum yang mengatur secara jelas mengenai bentuk pertanggungjawaban pidana korporasi sebagai subjek hukum pidana, khususnya subjek hukum tindak pidana pencucian uang, sehingga menyebabkan penegak hukum mengalami kesulitan dan kebimbangan dalam menjerat korporasi sebagai pelaku tindak pidana khususnya tindak pidana pencucian uang. 


\section{BIBLIOGRAFI}

Elwi Danil. (2014). Korupsi, Konsep Tindak Pidana dan Pemberantasannya. Jakarta: Rajawali Pers. Google Scholar

Chairul Huda. (2014). Dari Tiada Pidana Tanpa Kesalahan Menuju, Tiada Pertanggungjawaban Tanpa Kesalahan, Jakarta: Prenada Kencana Media Group. Google Scholar

Jan Remmelink, (2003). Pidana, Komentar atas Pasal-pasal Terpenting dari KUHP Belanda dan Padanannya dalam KUHP Indonesia. Jakarta: Gramedia. Google Scholar

Indriyanto Seno Adji. (2009). Korupsi Kebijakan Aparatur Negara dan Hukum Pidana. Jakarta: CV. Diadit Media. Google Scholar

Adami Chazawi. (2006). Hukum Pembuktian Tindak Pidana Korupsi. Bandung: PT Alumni. Google Scholar

Yusuf Shofie. (2002). Pelaku Usaha, Konsumen dan Tindak Pidana Korporasi. Jakarta: Ghalia Indonesia. Google Scholar

Muladi dan Dwidja Priyatno. (2010) Pertanggungjawaban Pidana Korporasi, Prenaca. Jakarta: Kencana Media Group. Google Scholar

Jan Remmelink (2003). Pidana, Komentar atas Pasal-pasal Terpenting dari KUHP Belanda dan Padanannya dalam KUHP Indonesia. Jakarta: Gramedia. Google Scholar

Chaidir Ali. (1992). Yurisprudensi Indonesia Tentang Hukum Pidana Ekonomi. Bandung: Bina Cipta. Google Scholar

Sahuri Lasmadi, Elly Sudarti. (2021). Pembuktian Terbalik Pada Tindak Pidana Pencucian Uang, Jurnal Ilmu Hukum FH Universitas Kristen Satya Wacana Vol. 5, No. 2, 2021, 201-202. Google Scholar

Afrianto Sagita. (2017). Pembalikan Beban Pembuktian Sebagai Kebijakan Hukum Pidana Dalam Undang-Undang Tindak Pidana Korupsi, Jurnal Hukum Republica, Vol. 17, No. 1, 34-35. Google Scholar

Naomi Ester. (2014). Penegakan Hukum Tentang Tindak Pidana Pencucian Uang (Money Laundring) Kaitannya dengan Penerapan Kerahasiaan Bank Sebagai Suatu Wujud Pembangungan Perbankan, Tesis. Universitas Jayabaya. Google Scholar

Supono. (2016). Beban Pembuktian Terbalik Tindak Pidana Pencucian Uang Dalam Perspektif Teori Pembuktian Pada Sistem Peradilan Pidana di Indonesia, Tesis. Universitas Jayabaya. Google Scholar

Lisa. (2018). Peran Perbankan Dalam Mencegah dan Menanggulangi Praktek Tindak Pidana Pencucian Uang dan Dampaknya Terhadap Kegiatan Perbankan Secara Online, Tesis. Universitas Jayabaya. Google Scholar

Yoses Kharismanta Tarigan. (2020). Pemidanaan Terhadap Korporasi dan Personil Pengendali Korporasi Dalam Tindak Pidana Pencucian Uang dan Tindak Pidana 
Korupsi (Studi Kasus Putusan No. 47/Pid.Sus-TPK/2019/PN. Smg), Tesis. Tarumanegara. Google Scholar

Sahbana Pilihanta Surbakti. (2018). Analisis Yuridis Penanganan Perkara Tindak Pidana Pencucian Uang Oleh Korporasi (Analisis Terhadap Perma No. 13 Tahun 2016 Tentang Tata Cara Penanganan Perkara Tindak Pidana Oleh Korporasi), Tesis. Universitas Sumatera Utara. Google Scholar

Shinto Bina Gunawan Silitonga (2011). Penegakan Hukum Tindak Pidana Korupsi dan Money Laundering Dengan Sistem Pembuktian Terbalik. Tesis. Universitas Indonesia. Google Scholar

First publication right:

Jurnal Syntax Fusion: Jurnal Nasional Indonesia

This article is licensed under:

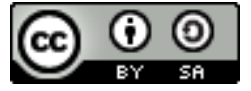

